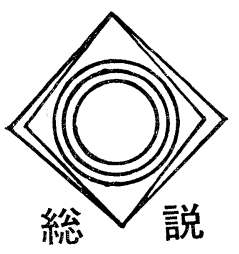

1. はじめに

都市と対比されるもの浱漁村，めるいは地方とい うことであろらが，両者は気候的条件，社会的条件な ぞの相違という点で太陽熱利用の有効性, あり方に影 響を与えている。

気候的な要素ではたとえば東京や大阪などの都心部 の日射量が地方，あるいは周辺部に較べて少ないこと は太陽熱温水器などの都市部への普及のひとつの妨げ となっていることは否めない。(図 1 , 図 2 参照) 逆の 面では冬期の都心部の気温が高いという現象は太陽熱 利用の場合, 常に課題となる凍結事故の軽減といら面 で利点となることも考えられる。また，社会的な条件 という点では, 現在, 特に地方で太陽熱温水器が使わ れる理由の一つにL P ガスが高価であり，それとの経 済比較で採用されるといらことがあるが, 都市部では 都市ガス供給が確保されていて一般にL P ガスより安
東海大学 田中俊六

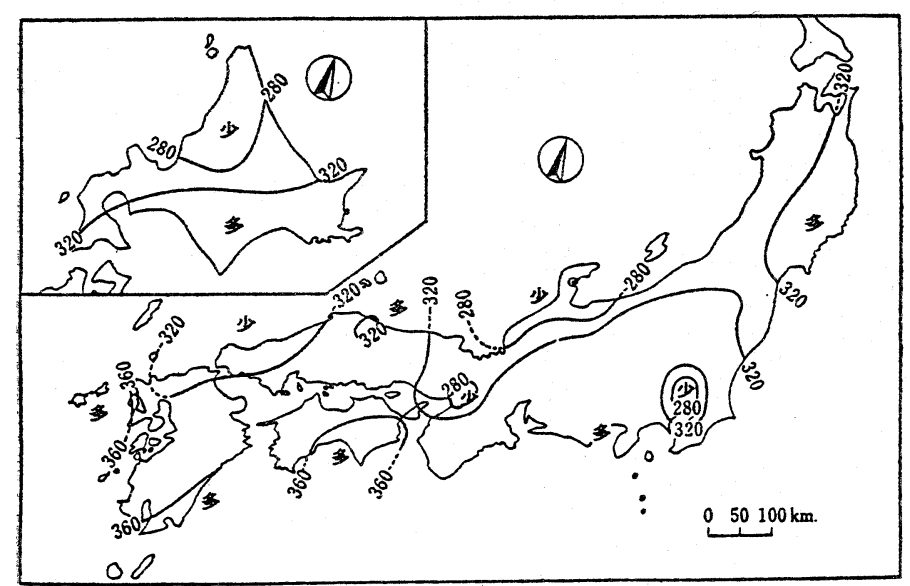

図 1 日本の年平均全天日射量地図 $\left[\mathrm{cal} / \mathrm{cm}^{2} \cdot \mathrm{day}\right]^{1)}$

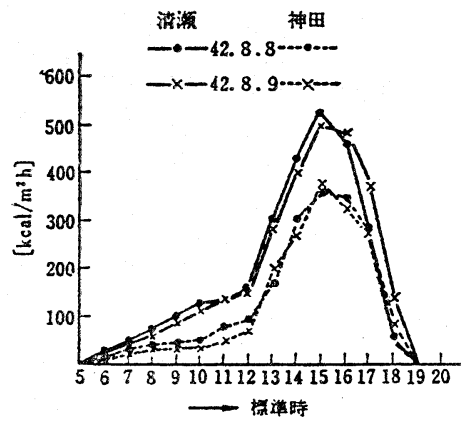

図 2 東京都心部亡郊外の日射量 比較 ${ }^{2}$ (西側垂直面)

1） サンシャイン計画委託報告書 (50-3)：太陽エネルギーシステム気象資料 No.1 N N o. 3 日本気象協会

2）田中，田中 (辰) 他, “東京の日射量に関する考察”，日本建築学会関東支部論文集 S 43-5 


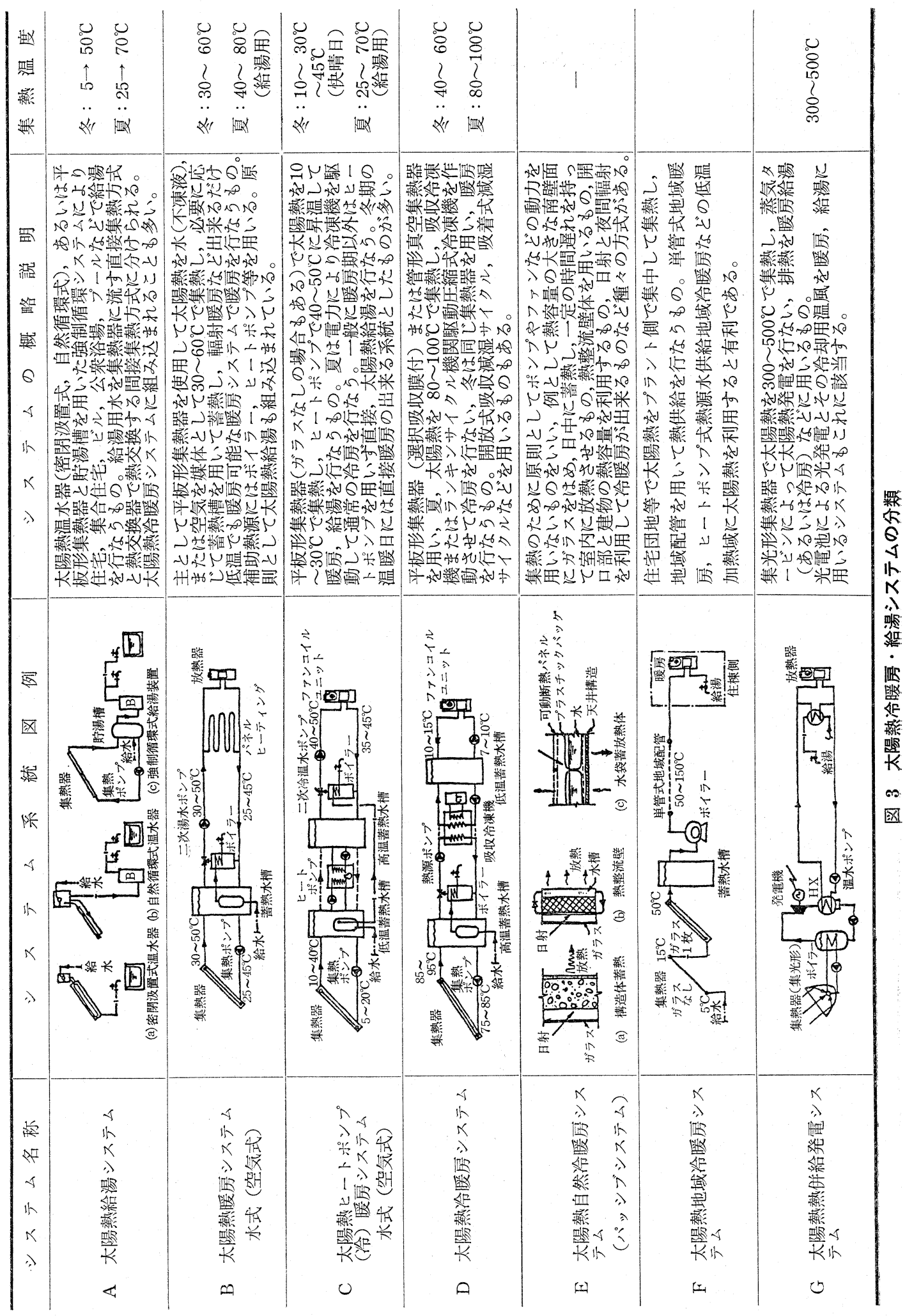




\section{2. 太陽熱利用の概要}

㕕義に太陽エネルギー利用として考兄られている対 象は太陽熱冷暖房・給湯, 太陽 熱 発電, 光発電, 蒸 溜, 乾燥など太陽エネルギーの直接利用と水力発電, 風力発電, 海洋温度差発電, あるいは光合成を利用し たアルコール燃料の製造，メタンの生成などの間接利 用といらように非常に広範囲にわたっている。これら の中で都市の中で得られ, 近い将来, 在来のエネルギ 一供給システムそ多少とも影響すると見られるのは言 らまでもなく太陽熱冷暖房・給湯の分野である。ま た，多少，先になれば太陽電池による光発電る実用に 供される可能性がある。さらに, 最近の都市ごみの焼 却に伴なら発電, 排熱利用はごみの中の可然物が漂之 んぞ光合成によって出来た有機物であることを考えれ ば太陽エネルギー利用のひとつである。

現在考兄られている太陽熱冷暖房・給晹システムに は図 3 に示したようにいろいろなるのがあるが，これ らの実用性, 経済性の程度には大きな差があり, 給湯 はすでに広く実用に供されているが，冷暖房はまだ試 験の域を脱していない。これは在来の化石燃料が燃焼 によって容易に 1,000 度以上の高温が得られ, 熱利用 にも動力利用にも広い汎用性を持っているのに対し, 太陽エネルギーが本来は 6,000 度の物体が出す電磁波 という高位のエネルギーではあるが現実の集熱装置の 効率やコストが集熱温度の関数となり, 利用目的, 特 に利用温度域によって得られた熱エネルギーのコスト が大幅に異なってくることに起因している。

太陽熱給湯は住宅などでは負荷が一年間にわたって 比較的安定してあり,また, 常に低温の給水温度から 加熱するために太陽熱の利用効率が高いので最も経済 性が出やすく, 太陽熱温水器として広く普及してい る。最近では住宅用により高級な強制循環式の給湯シ ステムも市販され, ホテル, 寮, 工場, 公衆浴場など の大規模給湯, プール加熱等も盛んに実施されてい る。

太陽熱暖房も利用温度域が30 $60^{\circ} \mathrm{C}$ の低温利用分野 であるが，断熱強化と競合関係にあり，地域によって は利用期間が短かく経済性を得るのは容易でない。太 陽熱暖房に見合う壁体の断熱材の厚さは秥およそ 150 $\mathrm{mm}$ 位と考えられるが, 現状ではこれ以下の断熱材の ままで太陽熱利用を考えている場合も少くない。断熱 を強化し, 建物の熱容量をある程度確保すれば空や壁 体に当る日射熱をうすく利用すればほとんぞ補助熱源 を用いずに室内を必要な温度に保てる。これがいわゆ るパッシブソーラーハウスである。特に日本の太平洋
表 1 住宅エネルギー用途別割合

\begin{tabular}{|c|c|c|c|c|}
\hline \multicolumn{2}{|c|}{ 用 } & 途 & 割 & 合 \\
\hline 䁔 & 房 & 用 & 30.0 & \\
\hline 冷 & 房 & 用 & 1.2 & \\
\hline 給 & 湯 & 用 & 29.1 & \\
\hline 厨 & 房 & 用 & 14.9 & \\
\hline 照 & 明・テ & レ ビ & 6.4 & \\
\hline 動 & 力 & 用 - 他 & 18.4 & \\
\hline 合 & & 計 & 100 & \\
\hline
\end{tabular}

沿岸地域は世界の先進国の人中集中地域では例外的に 冬季の日照率が高く, 太陽熱暖房, 特にパッシブシス テムに快有利である。北関東から東北南部，北海道東 南部は冬の日照が比較的多く，暖房期間が長いため太 陽熱暖房に有利である。

一方，太陽熱冷房は吸収冷谏機を用いても，ランキ ンサイクル機関駆動方式を用いてもいずれも熱力学的 には温熱から冷熱へのエネルギー変換を伴ならために 少なくとも $80^{\circ} \mathrm{C}$ 以上の高熱源と複雑な装置, 補機動力 を要して経済性が出にくく，現状では実験の域を出て いない。特に住宅用のような小容量システムは割高で 将来, 実用化するとすれば，オフイスビルや各種公共 施設などの大容量システムとなろう。

この泳か, シリカゲルなどの吸着剤, 塩化りチュー ム氷溶液などの吸収剂を用いた開放式冷房システムの 研究も行われているが実用に至っていない。

\section{3. 都市における太陽熱給湯とその課題}

住宅のエネルギー消費の中で給湯用は表 1 に示すよ らに約 $30 \%$ を占める。暖房用エネルギーは断熱の強化 で比較的容易に軽減され，特に都市に多い集合住宅で は現状でも非常に少ないが，給湯用は生活水準の向上 と共に増々増加するものとみられる。したがって住宅 の省エネルギー対策上, 重要な意味を持っている。

太陽熱給湯システムには図 4 に示すような汲置き式 と自然循環式のいわゆる太陽熱温水器と図 5 の強制循 環式給湯システムがある。汲置き式は古くから農家を 中心に使われてきたものであるが，安価で性能も悪く なく, 日没後，すぐに入浴する農家では不便なく利用 されてきた。ところが汲置式は貯湯部が外に面してい るために冷めやすい欠点があり, 耐久性す7〜10年と 短かかった。最近では入浴時刻が遅く，また風呂以外 にも給湯したいといら生活の変化と都市近郊でも使わ れるようになって夜でも温度降下の少ない自然循環式 が増光ている。 


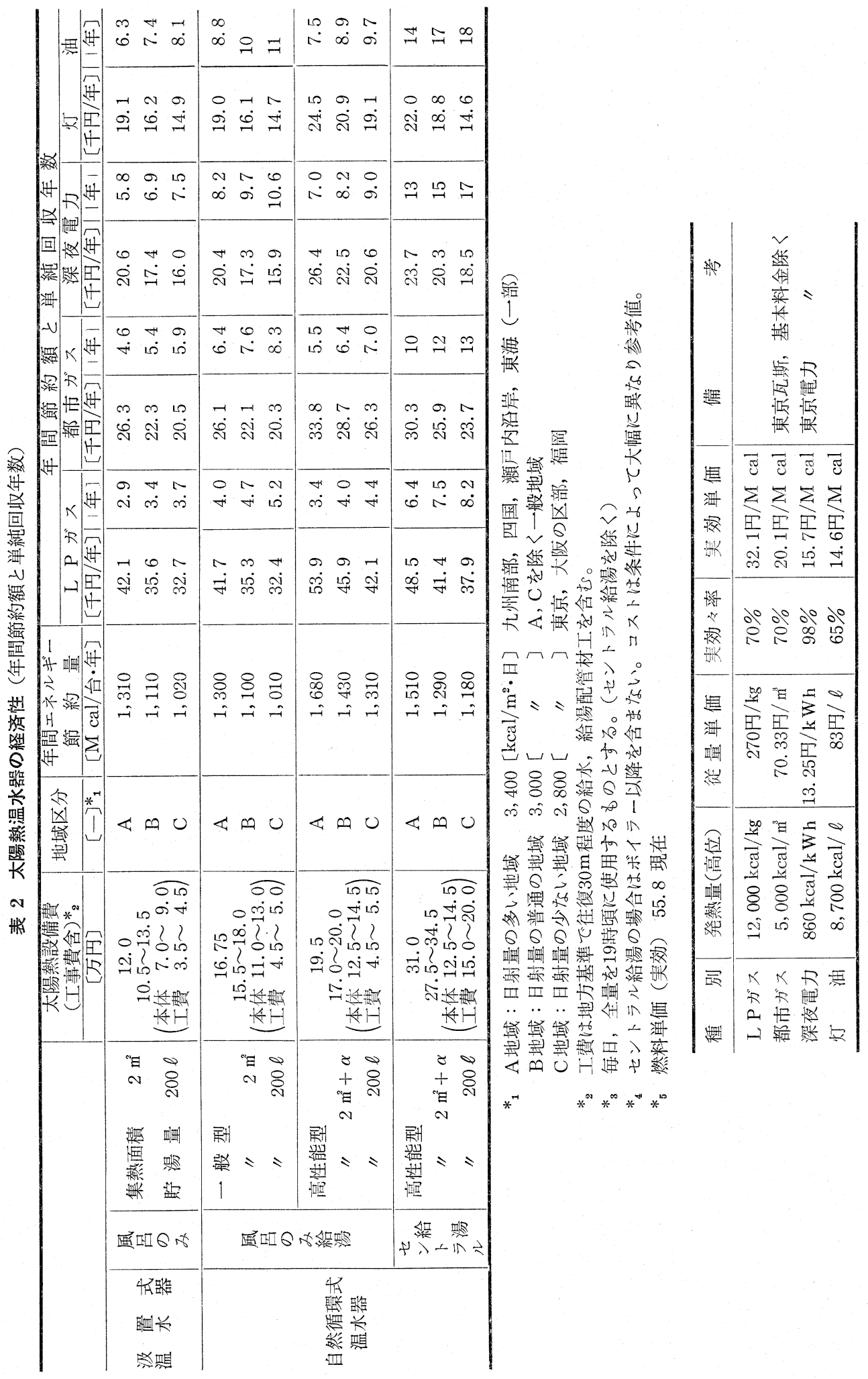




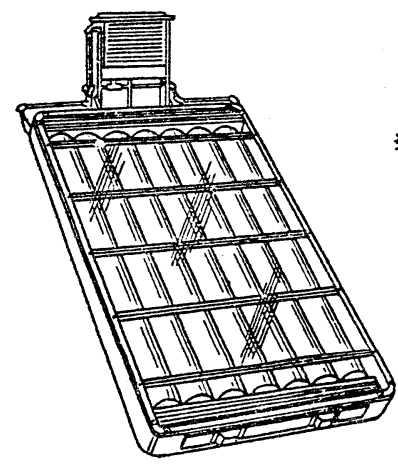

密閉汲跙式温水器

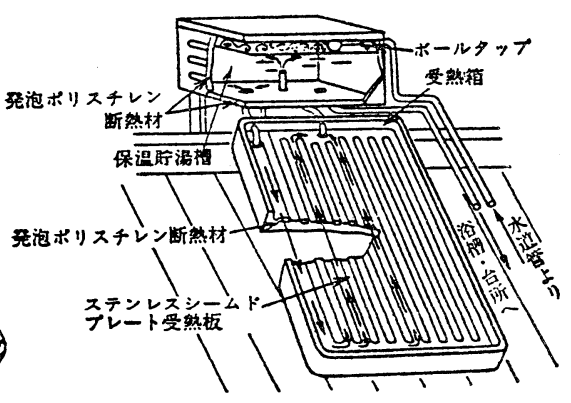

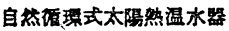

図 4 太陽熱温水器

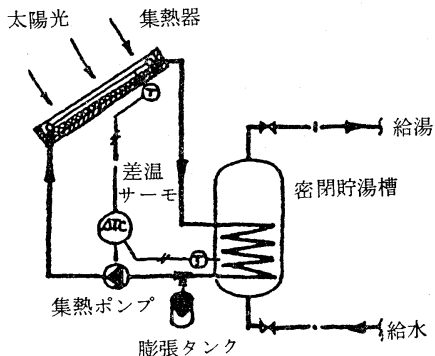

(a) 間接集熱式

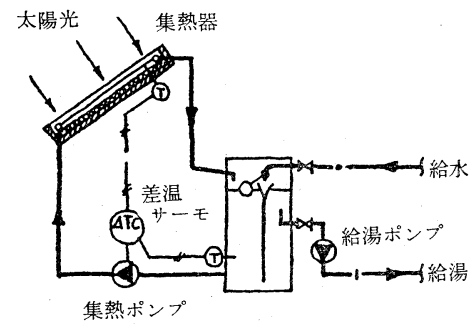

(b) 直接集熱式

図 5 強制循環式給湯システム

太陽熱温水器の経済性は条件によって差があるが， 大体，表 2 に示した通りである。比較対象となる然料 の価格とその地域の日射量の多寡で回収年数が異な る。都市ガスはL P ガスよりも一般に安いためと, 都 市では日射が少ないために経済性の点では都市は二重 のハンデキャッブがあるといえる。深夜電力について は 2 つ意味で注意が必要である。1つは深夜電力は 熱量当りの平均単価は都市ガスと同等かやや高いが, 基本料金が比較的大きな比重を占め，従量分が少ない ため太陽熱で熱量的に50\%を供給しても料金は半分に はならない。したがって深夜電力の場合は安い灯油と 回収年数が余り違わなくなっている。都市ガスの場 合, 従来は最低責任使用量のある料金制度であったが 省エネルギー的な観点から基本料金と従量料金の併用 制となったので深夜電力と同じような状況にあるが, 基本料金の比率が少ないので余り大きく影響しない。 資本費の償却などの観点からは止むを得ない面もある が省エネルギーを推進するといら点からこれらの料金 制度が見直されても良いのではなかろらか。その場 合，基本料金の低下と従量料金の使用量別瓜増制が考
えられる。しかしながら現実的にはシステム設計上， 基本契約量を減らすことが重要であるが太陽熱の間欠 性が障害である。2つめは当然のことながら電力を熱 エネルギーとして使用するといら熱効率上の問題であ る。太陽熱で給湯に必要なエネルギーの50\%を供給し ても太陽熱を使用せずガスのみで給湯した方が一次工 ネルギーの投入量は少ないことが充分考えられる。こ の問題は経済性, 安全性, 耐久性, 一次エネルギー源 の種類と供給方式などトータルで考えてゆく必要があ る。深夜電力の発電が石油やガスのように家庭でも使 用でさる燃料で行われるのではなく，石炭や水力，原 子力などによって扣もに行われるか，熱併給発電が一 般化すれば状況は変ってこよう。

戸建住宅の強制循環式給湯システムは表 3 のように 回収年数が非常に長く，すっとコストダウンを計る必 要がある。

集合住宅の太陽熱給湯システムには図 6 のような 4 つの基本形式が考えられる。(a)は完全な集中給湯シス テムで熱源が集約され, 機器効率, 安全性の面で優れ ているが，配管熱損失が大きくなりやすく，水および 
表 3 強制循環式給湯システムの経済性

（a）間接集熱（熱交換）万式

\begin{tabular}{|c|c|c|c|c|c|c|c|c|c|c|c|}
\hline & \multirow{4}{*}{ 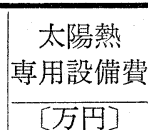 } & \multirow{2}{*}{\multicolumn{2}{|c|}{ 年間エネルギー }} & \multirow{3}{*}{$\begin{array}{c}\text { 袖 機 } \\
\text { 使用量 }\end{array}$} & \multirow{3}{*}{$\begin{array}{l}\text { 動 万 } \\
\text { 料 金 }\end{array}$} & \multirow{3}{*}{ 維持管理費 } & \multicolumn{4}{|c|}{ L P ガ ス } \\
\hline & & & & & & & & 年間実質 & 回 & 収 年 & 数 \\
\hline & & & \multicolumn{2}{|c|}{$\begin{array}{c}\text { 年 悢 量 }\end{array}$} & & & & 節約額 & $\imath=9$ & $i=12$ & $i=15$ \\
\hline & & & \multicolumn{2}{|c|}{ [M cal/年] } & [kWh/年] & [円/年] & [円/年] & [千円/年] & [年] & [年] & [年] \\
\hline \multirow{4}{*}{$\begin{array}{l}\text { 集 } \\
\text { 熱 } \\
\text { 体 }\end{array}$} & \multirow{2}{*}{$\begin{array}{c}\text { プラスチック } \\
\text { (黑色) }\end{array}$} & \multirow{2}{*}{$45 \sim 55$} & 普通 & 1,330 & 80 & 2,720 & 5,000 & 35.0 & 16 & 13 & 12 \\
\hline & & & 良好 & 1,530 & 80 & 2,720 & 5,000 & 41.4 & 13 & 11 & 10 \\
\hline & \multirow{2}{*}{$\begin{array}{l}\text { 金属 } \\
\text { (黒色) }\end{array}$} & \multirow{2}{*}{$50 \sim 60$} & 普通 & 1,480 & 80 & 2,720 & 5,500 & 39.3 & 15 & 13 & 11 \\
\hline & & & 良好 & 1,700 & 80 & 2,720 & 5,500 & 46.4 & 13 & 11 & 10 \\
\hline \multirow{2}{*}{$\begin{array}{l}\text { 型 } \\
\text { 式 }\end{array}$} & \multirow{2}{*}{$\begin{array}{l}\text { 金属 板 } \\
\text { (選択膜) }\end{array}$} & \multirow{2}{*}{$55 \sim 65$} & 普通 & 1,580 & 80 & 2,720 & 6,000 & 42.0 & 16 & 13 & 12 \\
\hline & & & 良好 & 1,820 & 80 & 2,720 & 6,000 & 49.7 & 13 & 11 & 10 \\
\hline
\end{tabular}

(b) 直接集熱方式

\begin{tabular}{|c|c|c|c|c|c|c|c|c|c|c|c|}
\hline & \multirow{4}{*}{$\begin{array}{c}\begin{array}{c}\text { 太陽熱 } \\
\text { 専用設備費 } \\
\text { [万円] }\end{array} \\
\end{array}$} & \multirow{2}{*}{\multicolumn{2}{|c|}{ 年間エネルギー }} & 補 機 & 力* & \multirow{3}{*}{ 維持管理費 } & \multicolumn{4}{|c|}{$\mathrm{L} \quad \mathrm{P}$ ガ ス } \\
\hline & & & & & \multirow{2}{*}{ 使用量 } & \multirow{2}{*}{ 料 } & & \multirow{2}{*}{$\begin{array}{l}\text { 年間実質 } \\
\text { 節約額 }\end{array}$} & 回 & \multicolumn{2}{|c|}{ 収 年 数 } \\
\hline & & & 節 & 量 & & & & & $i=9$ & $i=12$ & $i=15$ \\
\hline & & & {$[\mathrm{M}$} & $\mathrm{cal} /$ 年] & $\mathrm{kWh} /$ 年 & [円/年] & 门円/年1 & [千円/年] & [年] & [年] & [年] \\
\hline \multirow{2}{*}{$\begin{array}{l}\text { 集 } \\
\text { 熱 }\end{array}$} & \multirow{2}{*}{$\begin{array}{c}\text { プラスチック } \\
\text { (黑色) }\end{array}$} & \multirow{2}{*}{$50 \sim 60$} & 普通 & 1,570 & 180 & 6,120 & 6,000 & 39.2 & 15 & 13 & 11 \\
\hline & & & 良好 & 1,810 & 180 & 6,120 & 6,000 & 46.9 & 13 & 11 & 10 \\
\hline \multirow{2}{*}{$\begin{array}{l}\text { 体 } \\
\text { の }\end{array}$} & \multirow{2}{*}{${ }_{\text {(蝫色) }}^{\text {属 }}$} & \multirow{2}{*}{$60 \sim 70$} & 普通 & 1,740 & 180 & 6,120 & 6,500 & 43.2 & 16 & 14 & 12 \\
\hline & & & 良好 & 2,000 & 180 & 6,120 & 6,500 & 51.6 & 14 & 12 & 11 \\
\hline \multirow{2}{*}{$\begin{array}{l}\text { 型 } \\
\text { 式 }\end{array}$} & \multirow{2}{*}{$\begin{array}{l}\text { 金遇 板 } \\
\text { (選択膜) }\end{array}$} & \multirow{2}{*}{$65 \sim 75$} & 普通 & 1,860 & 180 & 6,120 & 7,000 & 46.6 & 16 & 14 & 12 \\
\hline & & & 良好 & 2,140 & 180 & 6,120 & 7,000 & 55.6 & 14 & 12 & 11 \\
\hline
\end{tabular}

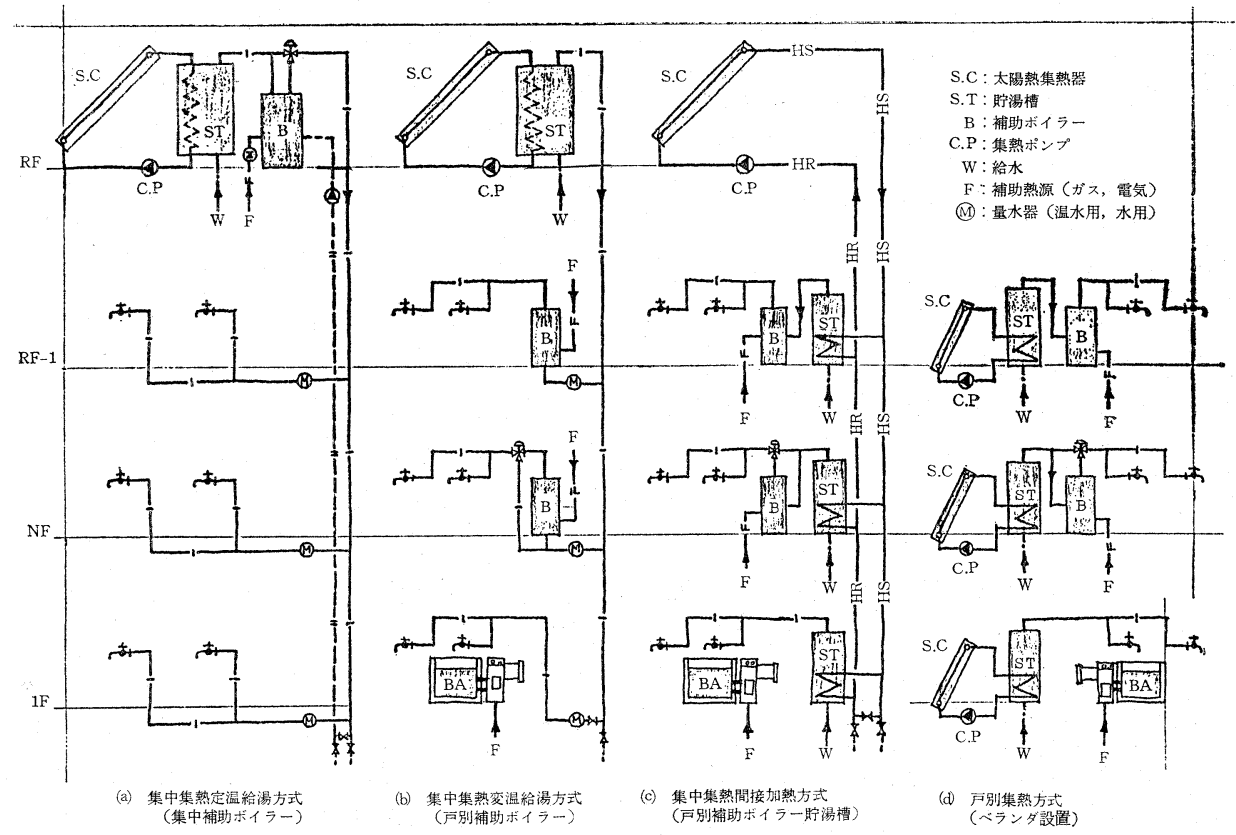

図 6 集合住宅用太陽熱給湯システムの基本 4 システム 
（年間節約額と回収年数）

$$
\mathrm{A}_{\mathrm{c}}=3.5 \mathrm{~m}^{2} \quad \mathrm{~V}_{\mathrm{w}}=300 \ell \quad \theta=30^{\circ} \quad \alpha=0^{\circ} \quad \text { (東京) }
$$

\begin{tabular}{|c|c|c|c|c|c|c|c|c|c|c|c|}
\hline \multirow{3}{*}{$\begin{array}{l}\text { 都 } \\
\text { 年間実質 } \\
\text { 節約額 }\end{array}$} & \multirow{2}{*}{$\frac{\text { 市 }}{\text { 回 }}$} & \multicolumn{2}{|l|}{ 离 } & \multicolumn{4}{|c|}{ 深 夜 電 力 } & \multicolumn{2}{|l|}{ 灯 } & \multicolumn{2}{|l|}{ 渵 } \\
\hline & & 収 年 & 数 & 年間実質 & 回 & 収 年 & 数 & 年間実質 & 回 & 収 年 & 数 \\
\hline & $i=9$ & $\imath=12$ & $i=15$ & 節約額 & $i=9$ & $i=12$ & $i=15$ & 節約額 & $i=9$ & $i=12$ & $i=15$ \\
\hline [千円/年] & 年] & 年 & 年1 & [千円/年] & 年 & [年] & 年1 & [千円/年] & [年] & 「年〕 & [年] \\
\hline 19.0 & 29 & 21 & 18 & 13.2 & 41 & 28 & 22 & 11.7 & 47 & 30 & 24 \\
\hline 23.0 & 24 & 18 & 16 & 16.3 & 33 & 24 & 19 & 14.6 & 37 & 26 & 21 \\
\hline 21.5 & 28 & 21 & 17 & 15.0 & 40 & 27 & 22 & 13.4 & 45 & 30 & 23 \\
\hline 26.0 & 23 & 18 & 15 & 18.5 & 32 & 23 & 19 & 16.6 & 36 & 25 & 20 \\
\hline 23.0 & 28 & 21 & 18 & 16.1 & 41 & 28 & 22 & 14.3 & 46 & 30 & 23 \\
\hline 27.9 & 23 & 18 & 15 & 19.9 & 33 & 24 & 19 & 17.9 & 37 & 26 & 21 \\
\hline
\end{tabular}

$$
\mathrm{A}_{\mathrm{c}}=3.5 \mathrm{~m}^{2} \quad \mathrm{~V}_{\mathrm{w}}=300 \ell \quad \theta=30^{\circ} \quad \alpha=0^{\circ}
$$

(東京)

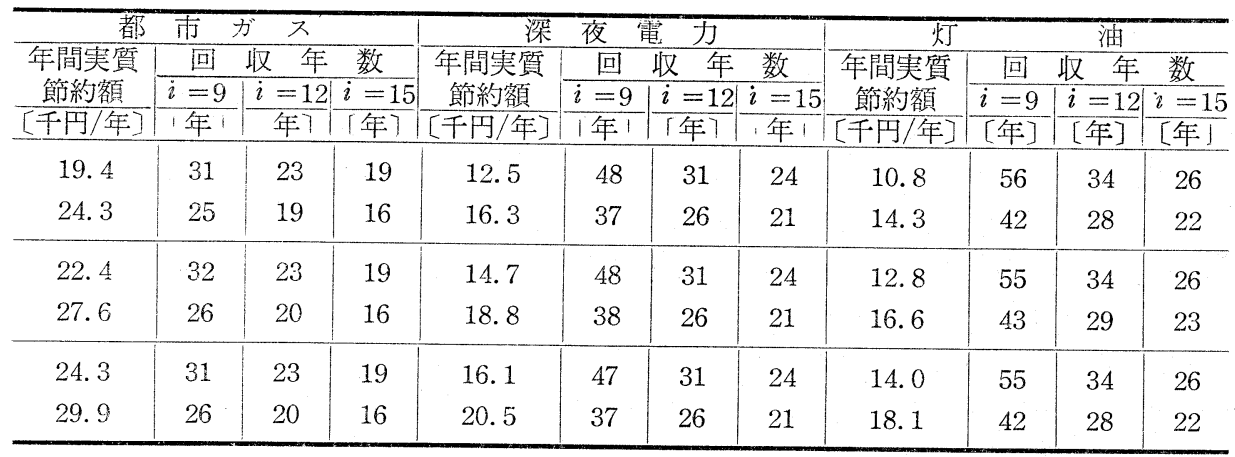

*1 加圧シスターン又は給湯ブースタポンプ動力を含む。

補助燃料の経費を徴収するため給湯メーターを設ける 必要がある。(b)は補助熱源が各戸に岁って計量は水の みでよいが，使用時間の早い者皇ど有利であるなどの 問題がある。(c)は各戸に貯湯槽, 補助ボイラーがあっ て居室内スペースがやや大きくなるが計量が必要な い。(d)手同様汇各戸計量の必要のない集熱器を各戸べ ランダに置く完全戸別式でめる。会社の社員寮など計 量を要しないときや質の高いセントラル給湯が望まれ る高級マンションには(a)の完全セントラル方式が向い ている。貸貸住宅では(c)の間接加熱式が好ましい。こ の場合は設備償却費と運転費を機椷的に各戸に割り振 ればよい。分譲マンションでは所有区分の明解な(d)の 完全各戸方式をとる場合が多い。金鉞上の管理は必要 ないが, 機器の維持補修の方法などは前もって考えて 括く必要がある。分譲マンションの場合も技術的には (c)の集中式間接加熱方式の方がよく, 将来は(c)が広く 用いられるものとみられる。

集合住宅の太陽熱給湯は従来のエネルギー供給に多 少の影響を及ほすす可能性がある。そのひとつはガス供
給に対するもので太陽熱給湯が行われると場合によっ ては給湯用熱量の半分以上がこれに奪われるので新ら しい団地計画でガス供給が成り立たなくなる可能性が ある。特に太陽熱は夏に多く，冬に少ないためガスの 需要形態としては最悪となる。なた，断熱化によって 暖房負荷は非常に少なくなっていることも考えられ， 供給量の絶刘量も少なくなり，設備投資額の回収が困 難となる。

逆にいえば図 7 のらな集合住宅の全電化システム は太陽熱利用があることによってェネルギ一的にも正 当化される。この場合, 太陽熱利用の経済性は二次的 となり, 全システムの設備費, 維持費, 安全性から評 価が行われることとなる。

太陽熱温水器に対しては住宅金融公庫の割增融資, ソーラーシステムに対しては通産省の低利融資, さら には地方自治体の各種助成措置など太陽熱給湯システ ムの普及促進策がとられるにつれ，この分野に参入す る企業は急速に増加し, 温水器の生産量も54年度が30 〜40万台であったものが55年度は約 80 万台が生産され 


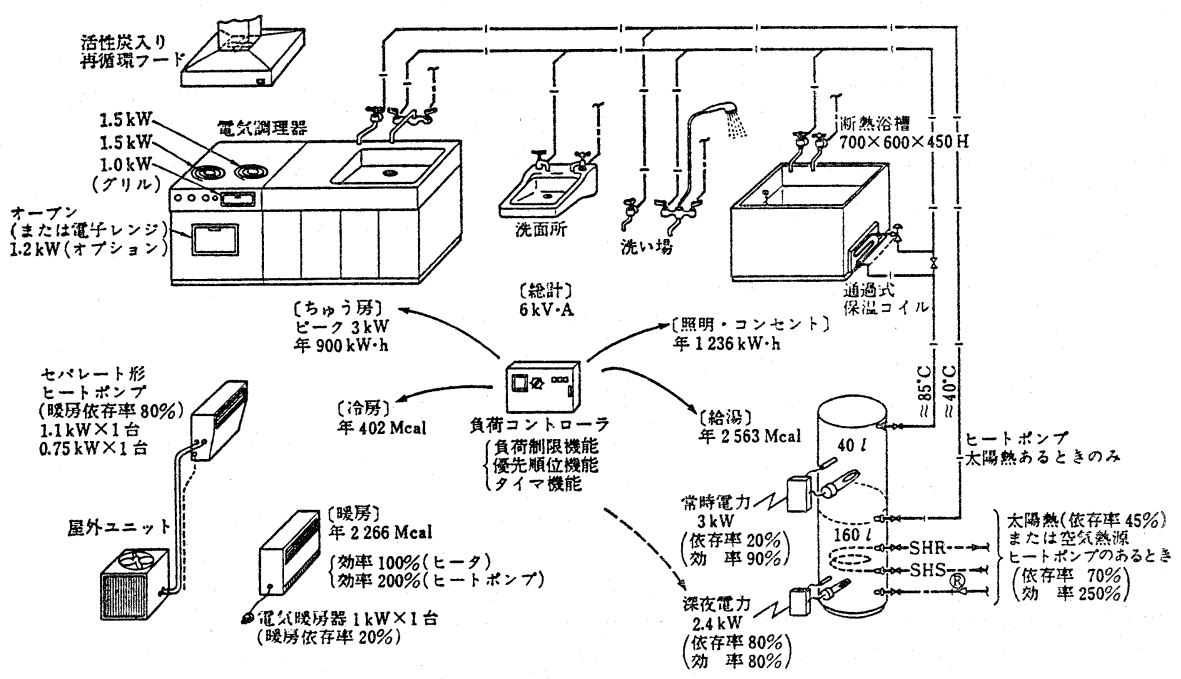

図 7 全電化集合住宅設億の概念

るものとみられている。ところが生産能力はすでに年 産 250 万台位あるとされ，すでに供給過剩に入りつつ ある。これに対し, 温水器の需要は昭和60年度位まで 横這いで年間 100 万台位が販売されるものとみられて いる。一方, 強制循環システムは始まったばかりであ るが，現状の年産約 3 万セットから昭和60年には30万 台弱の生産量が見込まれている。(財)住宅部品センタ 一の「太陽熱給湯システム委員会」の予測では昭和54 年迄のストック, 約 200 万台に対し, 昭和 60 年にはわ が国の約 3,900 万台の住宅のらち約 800 万戸近くが何ら かの形で太陽熱給湯を行らものとして拈り，その場合 の石油節約量は年間約 200 万kもと通産省の見通しど㜿 りとなっている。

\section{4. 太陽熱暖房の楔題}

前述のように太晹熱暖房は断熱と競合関係にあり， しかも断熱のコストは集熱器などの太陽熱利用機器の コストより安く, 酎久性も長く, 效果も確実である。 ただ単に断熱材の厚さと燃料節減効果とソーラーシス テムのそれを比較してみると東京などの温暖地域でも ソーラーコストに見合ら断熱厚さは $200 \mathrm{~mm}$ 越え る。ところが，日本の都市特有の高地価を考慮すると 木造住宅で間柱内の空間を利用できるとき以外，ある いはコンクリート造住宅などの外壁の断熱コストの大 半は地価相当分になることがあり，この場合は太陽熱 利用が有利になることがある。

住宅を対象とした太陽熱暖房の方法には太陽集熱器 と蓄熱槽, 放熱器, 集熱ポンプなどを用いるアクティ ブシステムと通常の集熱器を用いず建物に入る日射量
などを上手に利用するパッシブシステムに分類される がいずれの場合も断熱との競合するためにコストダウ ンをさらに一層強化しなければならない。

アクティブシステムでは屋根一体化などによって集 熱器をローコスト化すると共に耐久性を向上させ, 蓄 放熱床の利用など建物の熱容量をうまく使うことが不 可欠である。水集熱の場合と空気集熱の場合が考えら れるが簡易システムとしての後者が今後の研究課題と なろう。集熱器や蓄熱槽の必要な容量は断熱水準の向 上と共に小さくてすむよらになっており，たとえば籊 者らが担当した日本住宅公団の登戸職員宿舎の例では 一戸当りわずかに $10 \mathrm{~m}^{2}$ の集熱面積があるだけで，冬の 暖房負荷の95\%を太陽熱でまかなっている。この場 合, もし, 在来の大げさな暖房装置が不要という結論 が得られれば経済的なアクティブソーラーハウスとす ることも可能であろう。このためには徒来のように冬 季に常に一定の室温を保たなければならないといらよ らな暖房の常識に代って特別に気候条件が悪い日が続 けば室温が健康の許す範囲内でやや低くなってもよ く, 逆に太陽熱が十分得られる時には $22^{\circ} \mathrm{C}$ 以上に暖房 するといらよらな別の考光方も必要となる。

もらひとつの方法がパッシブシステムである。これ には図 8 のような各種の方法が考えられている。都市 住宅のよらに密集した住宅地では南側に十分な開口部 と日照を確保できるかどらかが問題である。

最近ではアクティブとパッシブを組及合わせたハイ ブリッドシステムが注目されている。図 9 は集合住宅 の提案例である。集合住宅では断熱を良くすると基準 


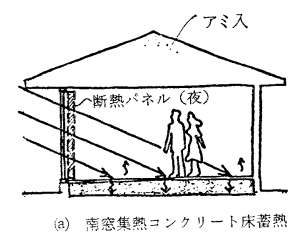

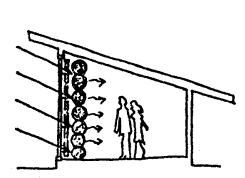

(b) 水ドラム集蓄䇾

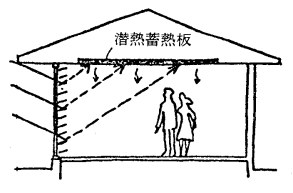

(g) 反射ルー・゙ー, 灭井潜熱蓄熱板 (MIT)
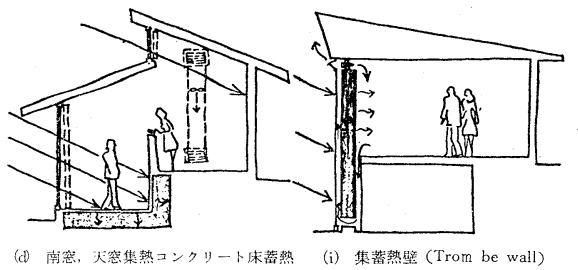

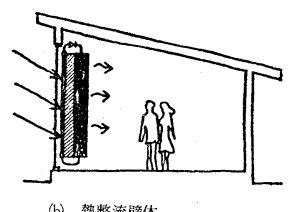

(b) 熱整流暨本

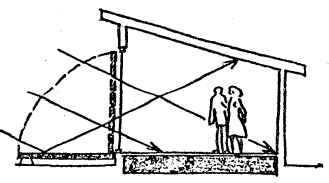

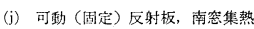
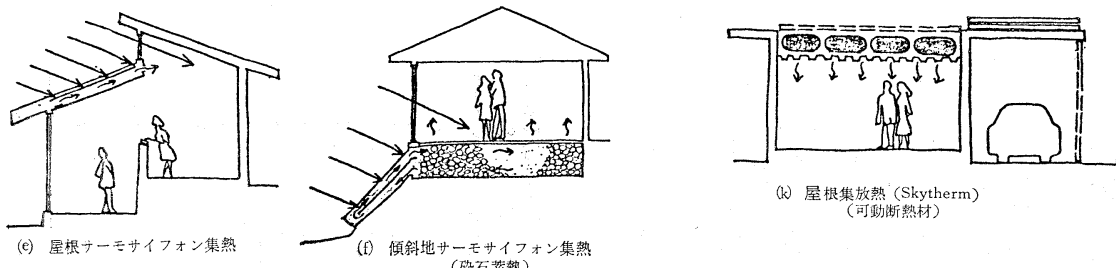

(k) 屋根集放熟 (Skytherm) (可㓰断崺材)

図 8 パッシブソーラーシステム

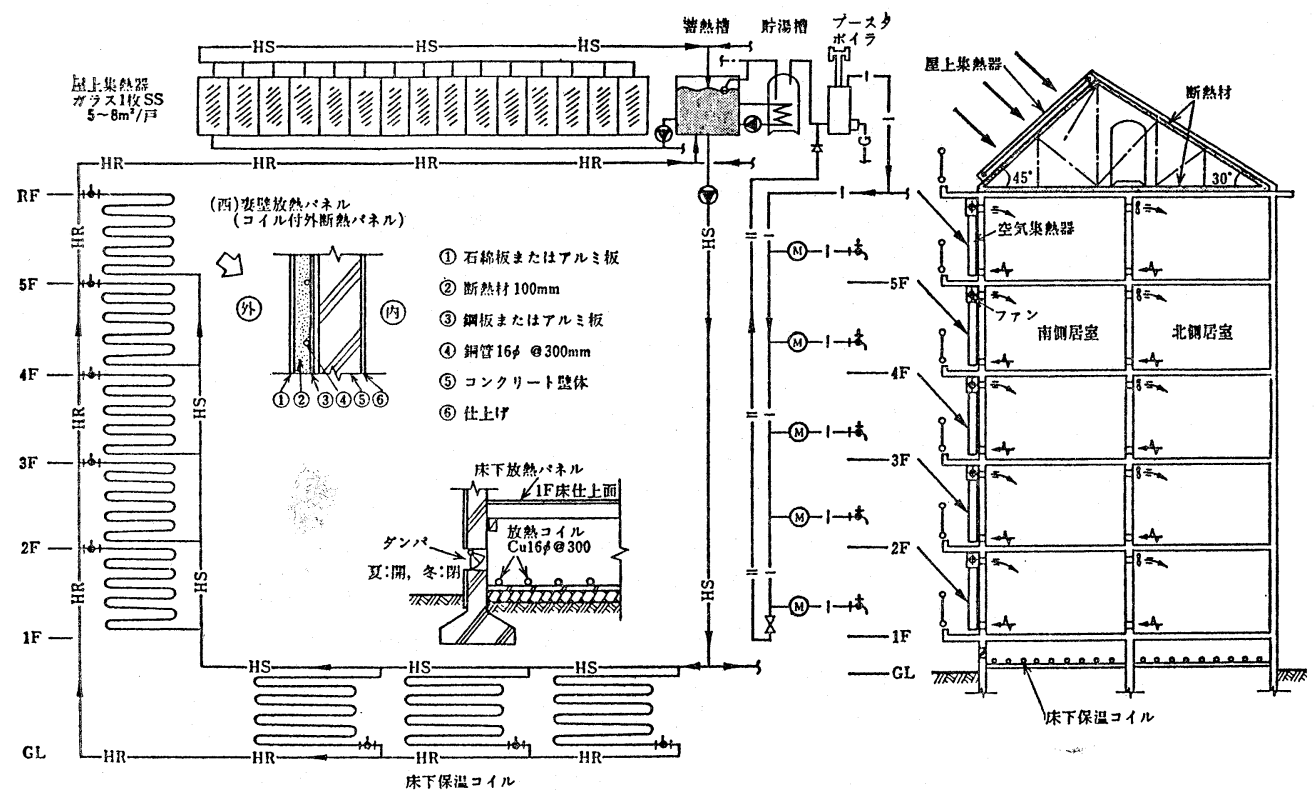

図 9 空気集熱十ペリメー夕補償式太陽熱暖房給湯システム

階の中間住戸は活とんど暖房負荷がなくなるが，不足 分は罒のよらに簡単な集熱壁で集熱し，主として北側 の部屋へ熱を送る。鉄筋コンクリート造の場合, 一般 に熱容量は十分に大きく, 外壁の断熱材が $50 \mathrm{~mm}$ 以上 あれば晴天日の室温の日振幅は $3{ }^{\circ} \mathrm{C}$ 位しかない。問題
は外周に面する住戸の熱損失をいか補らかである が，この場合は給湯用と兼用する屋上集熱器で集めた 熱を外周壁の補償暖房に用い, 各室の暖房負荷を均一 化するように考光ている。

\section{5. 太陽熱ヒートポンプ(冷)暖房の課題}




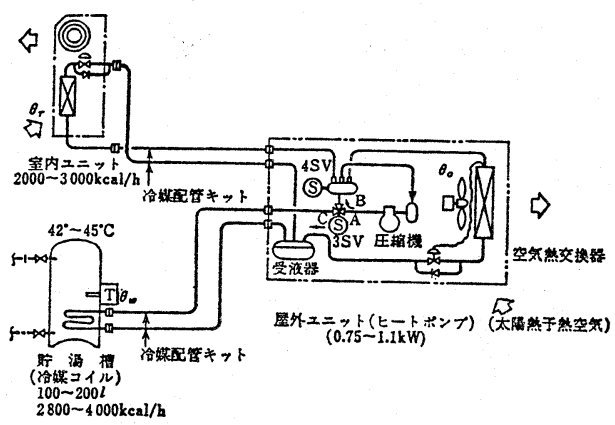

(a) 系統図

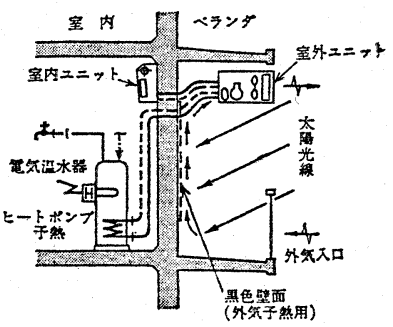

(b) 集合住宅ベランダへの適用例

図 10 給湯加熱式熱回双ヒートポンプエアコンの応用

太陽熱ヒートポンプ(冷)暖房システムは冬季, 太陽 熱を $10 〜 20^{\circ} \mathrm{C}$ の低温で効率よく集熱し，これを低熱源 として暖房を行い，夏は太陽熱とは直接関係なくヒ一 トポンプを冷涷機として電力によって冷房を行う方法 である。日本では1958年に建設された，世界的にも有 名な柳町ソーラーハウスがあり,ナガノソーラー八ウ ス, 三菱重工と積水化学が共同開発したプレハブ住宅 用システムなど特色のあるものがあるが，現在では住 宅用としてはヒートポンプシステムはあまり評価され ていない。その理由のひとつには日本の関東以南の冬 の気候が比較的, 温暖でいわゆる空気熱源ヒートポン プでも運転が可能でC O P (成績係数) も市まり低く ないことが上げられる。また，日本ではセントラル冷 䁔房を行らよらな住宅が流とんどないため，原則とし てセントラル型式となるソーラーシステムを組み込む 必然性とチャンスが少ないということもある。日本の ように住宅でも油学焼し，発電所でも油を使ってい るときはヒートポンプシステムの一次エネルギー基準 の成績係数が直ちに問題となるが，ヨーロッパ諸国で は発電用石炭を家庭で然焼するのは困難で市り, 熱併 給発電も行われているから, このような問題は直接, 出てこなくてすむ。このような意味で西独やフランス ではソーラーヒートポンプシステムの研究開発が盛ん である。

日本ではオフィスビルなどでの熱回収ヒートポンプ が盛んであるが，この場合は南空からの入射日射を使 っているといら意味ではパッシブなソーラーヒートポ ンプシステムとみることる出来る。また，ヒートポン プの厳冬期の不足熱源として太陽熱を利用するといら 考え方もあり，東電大塚支社ビルなどにとの一例をみ ることが出来る。

ソーラーヒートポンプシステムの一つのメリットと

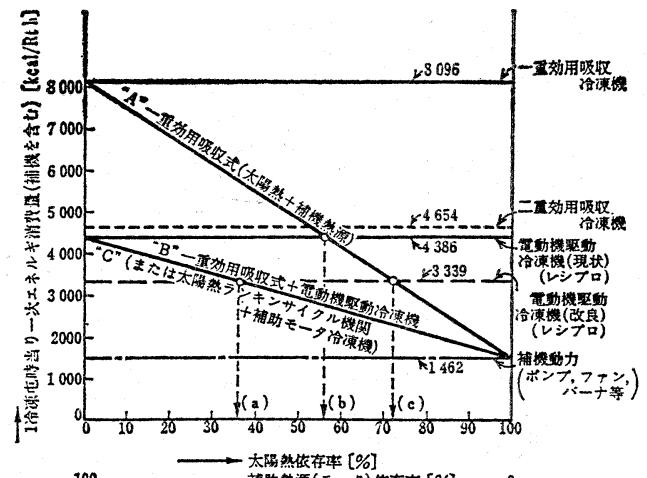

圈 11 冷房時の太陽熱依存率と換算一次エネル ギー消費量の関係

して冬の蓄熱槽は容易に夏の蓄冷槽として用いらるこ とでこれは都市に拉ける電力のピークカット対策に役 立つ可能性がある。

また，図10のような冷房の排熱を給湯用に回収利用 し, 中間期や冬期は太陽熱を一部, 補助熱源として利 用する集合住宅用の簡易なヒートポンプシステムが使 えるようになれば深夜電力温水器を使用する必要がな く省エネルギー的にもすぐれた全電化住宅を完成する ことが出来るようになろら。

\section{6. 太陽熱冷暖房}

大都市には冷房が不可欠な商業建築が多く, 住宅も また，劣悪な環境条件と熱污染によって気温が高いた め冷房の必要性が高く, 太陽熱冷房に対する期待は大 きい。しかしながら, 先述のように現在, 純技術的に は可能で実績のある吸収冷凍機方式でもこれを動かす 補機動力が大きく，また，この吸収冷凍機を補助熱源 で動かすとさのCOP（成績係数）が電動冷凍機（一 次エネルギー基準）や現在では当然の補助熱源駆動の 


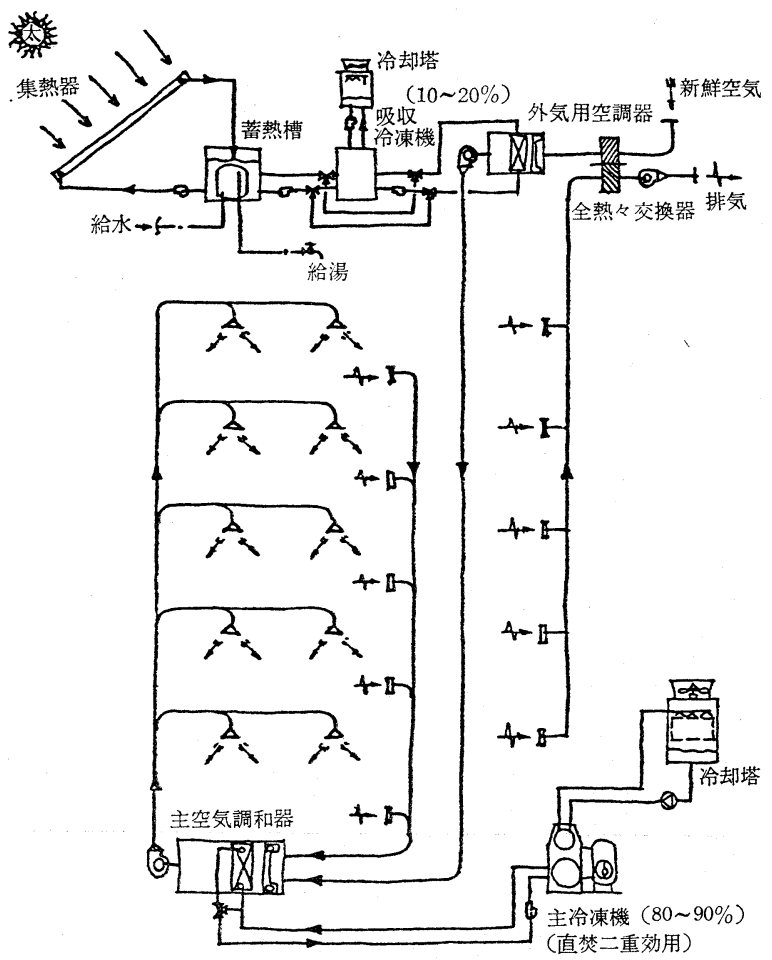

図 12 太陽熱によるビルの外気系統部分冷暖房システム（全ダクト方式）

二重効用形吸収冷凍機よりかなり低いために実質的な 省エネルギー効果を得ることが非常に困難である。図 11はこの点を検討したもので太陽熱冷房システムと 他の在来エネルギーによる冷房システムの冷房出力 $1 \mathrm{Rth}(3,024 \mathrm{kcal})$ を発生するのに必要な一次エネル ギーの必要量を太陽熱依存率の関数として求めたもの である。図のように現在, 最も開発が進んでいる一重 効用吸収冷凍機を用いる太陽熱冷房方式は太陽熱が得 られないときは成績係数の低いまま補助熱源で運転し なければならないため, 太陽熱と無関係な電動方式と 比較して太陽熱依存率が約 $56 \%$ (図の(b)点) 以上, 改 良可能な効率のよい電動方式と比較すれば“A”ライン のように72\%（図の(c)点以上でなければ省エネルギー 効果が出ない。一方, 吸収冷凍機を太陽熱のみで運転 し，太陽熱が得られないときは電動冷凍機を運転する 場合は“B”ラインのような特性となり，一応どのよ うな依存率でも多少は省エネルギー効果が出る。

このよらな観点から筆者らは科学技術庁の “草加太
陽の家”では冬季の補助熱源装置としての空気熱源と 一トポンプを太陽熱吸収冷谏機と併用する実験を行っ た。また，「サンシャイン計画」では太陽熱では一重 効用, 補助熱源では二重効用で作動する一重効用二重 効用組み合わせ式吸収冷凍機の提案を行い, これが大 分大学の実験棟で実施された。さらに, 太陽熱冷房を 最も効率よく, 経済的に行ら方法としてビルの外気系 統のみを冷(暖)房する方法が考えられる。(図12参照) このシステムでは屋上に設置した太陽熱冷房装置で夏 は高温, 冬は低温の外気系統のみを予冷, 予熱するも のでシステム効率が高く, 装置の容量をビルの冷房ピ ーク負荷の $10 \sim 20 \%$ 程度とすればこの部分に補助熱源 装置は特に不要である。このシステムは大阪瓦斯の酉 島導管センタ一事務棟で実験されている。

以上のように太陽熱冷暖房についても種々の工夫が なされているが，現状ではまだ実用化は困難で近い将 来, 都市のエネルギー需給, 特に電力のピーク対策に は期待できないと考えておいた方がよい。 


\title{
Solar Heating and Cooling in the Cities
}

\author{
Shunroku TANAKA
}

(Department of Architecture Faculty of Engineering, Tokai University)

SYNOPSIS :-Although there in not fundamental difference about the method or possibility between cities and contries, the climatic conditions and limited space conditions for putting solar collectors should be examined, when applying solar systems in big cities like Tokyo or Osaka.

At present, only the solar DHW supply systems using the solar water heaters are economically feasible. In the near future, the demand of city gas or off-peak electricity can be reduced in some new residential districts.

The solar heated houses are not so many. Insulation is more important in Japan.

The solar cooling systems are expected to cut peak load of electricity in summer, but they are too expensive and inefficient. And there is no expectancy that they could affect the demand and supply of electricity in the cities in the near future. 